\title{
Faktor-Faktor yang Mempengaruhi Produksi Usaha Tani Sayur Sawi di Kelurahan Bensone Kecamatan Kota Kefamenanu Kabupaten Timor Tengah Utara
}

\author{
Marselina Lama ${ }^{\mathrm{a}}$ dan Simon Juan Kune ${ }^{\mathrm{b}}$ \\ ${ }^{a}$ Fakultas Ekonomi dan Bisnis, Universitas Timor, Kefamenanu, TTU - NTT, 85613, Indonesia \\ ${ }^{b}$ Fakultas Ekonomi dan Bisnis, Universitas Timor, Kefamenanu, TTU - NTT, 85613, Indonesia.
}

\section{Article Info}

Article histor:

Received 27 Februari 2016

Received in revised form 4 Maret 2016

Accepted 23 Maret 2016

\section{Keywords:}

Cobb-douglas

Faktor Produksi

Usahatani Sawi

\begin{abstract}
Abstrak
Penelitian ini bertujuan untuk mengetahui gambaran umum usahatani sayur sawi dan juga faktor - faktor yang mempengaruhi produksi usahatani sayur sawi. Metode pengambilan sampel adalah simple random sampling dengan jumlah petani sebanyak 50 sampel. Analisis yang digunakan adalah analisis regresi linier berganda dalam bentuk logaritma dengan fungsi produksi CobbDouglas. Hasil uji F menunjukkan bahwa secara keseluruhan variabel bebas secara bersama-sama dapat menunjukkan pengaruhnya terhadap faktor produksi sawi dengan nilai Fhitung sebesar (712.476) > nilai $\mathrm{F}_{\text {tabel }}(2.32)$, sedangkan hasl uji $\mathrm{T}$ menunjukan bahwa faktorfaktor produksi yang berpengaruh secara nyata terhadap produksi sayur sawi di Kelurahan Bansone adalah faktor luas lahan dengan nilai thitung luas lahan (4.090) $>$ ttabel $(1,684)$, faktor benih dengan nilai $t_{\text {hitung }}$ benih(1.974) $>t_{\text {tabel }}(1.684)$, faktor modal dengan nilai thitung modal (2.479) $>t_{\text {tabel }}(1.684)$, faktor tenaga kerja dengan nilai $t_{\text {hitung }}$ tenaga kerja $(2.785)>t$ tabel(1.684) berpengaruh secara nyata terhadap produksi usahatani sayur sawi sedangkan faktor pupuk dengan nilai $t_{\text {hitung }}$ pupuk $(0.164)<\mathrm{t}_{\text {tabel }}$ (1.684), faktor pengalaman degan nilai $t_{\text {hitung }}$ pengalaman $(1.117)<\mathrm{t}_{\text {tabel }}(1.684)$ dan faktor pendidikan formal dengan nilai $\mathrm{t}_{\text {hitung }}$ pendidikan $(0.321)<\mathrm{t}_{\text {tabel }}(1.684)$ tidak berpengaruh secara nyata terhadap produksi usahatani sayur sawi. (2016 dipublikasikan oleh Agrimor.
\end{abstract}

\section{Pendahuluan}

Pembangunan pertanian di Indonesia pada umumnya berorientasi pada ketahanan pangan dan swasembada pangan, sektor pertanian yang mendominasi sekaligus sebagai sektor penyokong ekonomi di Indonesia dan sektor yang memperkuat ladasan peningkatan kesejahteraan masyarakat, selain itu sekto pertanian juga berperan sebagai roda penggerak bagi sektor-sektor lainya dengan memanfaatkan potensi dari sektor pertanian dalam hal ini bahan baku pertanian Upaya pengembangan potensi pertanian dapat di lakukan dengan meningkatkan penghasilan dari komoditi-komoditi andalan sesuai kondisi lokal.

Salah satu potensi yang besar dari sektor pertanian yaitu sektor holtikultura yang memiliki peran penting dalam mensuplay kecukupan gizi bagi masyarakat. Komoditas holtikultura diantaranya yaitu sayuran, buah-buahan, bunga, tanaman apotik hidup, dan sebagainya. Salah satu komoditas holtikultura yang berperan dalam mensuplay kecukupan gizi adalah sayuran, selain itu sayuran memiliki nilai ekonomis yang tinggi maka dari itu produktifitas dari komoditi ini harus benar-benar efisien sehinggah komoditi sayuran menjadi produk yan berkualitas dan dapat bersaing dalam pasaran baik didalam maupun luar negeri.

Sayuran merupakan komoditas hortikultura memiliki nilai tambah bag pembangunan nasional karena dapat memberi kontribusi yang signifikan terhadap peningkatan pendapatan dan kesejahteraan masyarakat. Kegiatan usahatani hortikultura khususnya komoditas sayuran yang saat ini mulai banyak dikembangkan, selain memiliki peranan yang sangat besar dalam pemenuhan gizi masyarakat, komoditas ini juga sangat potensial dan prospektif untuk dijalankan karena metode pembudidayaannya yang mudah dan sederhana. (Mufriantie dan feriady, 2014). Komoditi sayuran pada umumnya merupakan sumber vitamin, protein, dan lain-lain yang diperlukan untuk pertumbuhan, perkembangan kesehatan tubuh manusia dan peningkatan kualitas sumberdaya manusia, sehingga dari aspek sosialogis sayuran pada umumnya merupakan wahana peningkatan peran masyarakat dalam berinteraksi, baik antara sesame warga maupun dengan pembangunan masyarakat itu sendiri (Lamusa, 2005).

Sawi merupakan jenis sayur yang digemari oleh masyarakat Indonesia. Konsumennya mulai dari golongan masyarakat kelas bawah hingga golongan masyarakat kelas atas. Kelebihan lainnya sawi mampu tumbuh baik di dataran rendah maupun dataran tinggi. Sawi mempunyai nilai ekonomi tinggi setelah kubis krop, kubis bunga, dan brokoli. Sawi diduga berasal dari Tiongkok (Cina), tanaman ini telah dibudidayakan sejak 2500 tahun lalu, kemudian menyebar luas ke Filipina dan Taiwan (Rukmana, 2002).

Sawi bila ditinjau dari aspek ekonomis dan bisnisnya layak untuk dikembangkan atau diusahakan untuk memenuhi permintaan konsumen serta adanya peluang pasar. Kelayakan pengembangan budidaya sawi antara lain ditunjukkan oleh adanya keunggulan komparatif kondisi wilayah tropis Indonesia yang sangat cocok untuk komoditas tersebut, disamping itu, umur panen sawi relatif pendek yakni 40-50 hari setelah tanam dan hasilnya memberikan keuntungan yang memadai (Rahman et al., 2008).

Selain itu aspek teknis, ekonomi dan sosial juga sangat mendukung pengusahaan sayur di negeri kita. Ditinjau aspek teknis, budidaya sawi tidak terlalu sulit (Haryanto et al., 2006). Masa panen yang singkat dan pasar yang terbuka luas merupakan daya tarik untuk mengusahakan sawi. Daya tarik lainnya adalah harga yang relatif stabil dan mudah diusahakan (Hapsari, 2002).

Tanaman hortikultura menjadi komoditas unggulan di Kabupaten Timor Tengah Utara salah satunya yaitu sayuran. Menurut Data Badan Pusat Satistik Kabupaten Timor Tengah Utara produksi sayuran selama tahun 2010 sebesar 1.521 ton. Sawi dengan produksi sebesar 211 ton (BPS Kab, TTU 2014).

Usahatani sawi yang memiliki potensi sosial dan ekonomi yang besar ini dipandang sebagai salah satu usahatani yang dapat di kembangkan dan dapa meningkatkan kesejahteraan masayarakat, oleh karana itu para petani di kabupaten Timor Tengah Utara pun melakukan budidaya sawi. Menurut data dari Dinas Pertanian Kabupaten Timor Tengah Utara produksi sayur sawi dalam tiga tahun terakhir mengalami fluktuasi sehingga pada tahun 2012 produksi sawi sebanyak 125 ton, sedangkan dua tahun terakhir (2013 dan 2014) produksi sayur sawisebanyak67 ton dan 119 ton (Dinas Pertanian Kab, TTU 2014)

Kecamatan Kota Kefamenanu, terdapat salah satu kelurahan yang mensuplay sayuran yaitu Kelurahan Bansone dan sampai tahun 2014 kelurahan Bansone memproduksi sayuran sampai 18 ton dari luas lahan 8 ha. Jenis sawi yang banyak dibudidayakan di kelurahan Bansone yaitu sawi manis. Tanaman sawi ini memiliki bentuk daunberwarna hijau muda dan memiliki batang panjang berwarna putih. Sawi manis tahan terhadap air hujan dan tetap tumbuh dengan baik pada musim kemarau, asalkan pengairannya cukup. Selain itu tanaman sawi ini dapat dibudidayakan di dataran rendah dan dataran tinggi sehingga sangat cocok di daerah penelitian yang berada di dataran randah. Sawi yang diproduksi 500 kg/are (Kelurahan Bansone, 2014). Produksi sayur sawi diharapkan dapa terus meningkat, namun petani masih dihadapi dengan kendala faktor-faktor produksi antara lain luas lahan, modal, benih, penggunaan pupuk dan tenaga kerja yang dikelolah belum intensif, seta pengalaman usahatani akan menentukan tingkat produksi. Selain itu faktor perangsang seperti pendidikan baik formal maupun nonformal yang dilalui oleh petani akan mempercepat pengambilan keputusan dalam usahatani sayur sawi sehinggah produksi yang dihasilkan semakin tinggi.

\section{Metode}

Penelitian dilakukan di kelurahan Bansone kecamatan Kota Kefamenanu dari bulan oktober - bulan februari 2016 karena kelurahan ini merupakan salah satu kelurahan yang menghasilkan produksi sayur terbesar dikecamatan kota Kefamenanu. Pengumpulan data dilakukan dengan metode survei, data yang dikumpulkan berupa data primer dan data sekunder. Populasi dalam penelitian ini adalah seluruh petani yang menanam sayur sawi di kelurahan Bansone, menurut sumber di sekitar tempat penelitian yaitu jumlah petani yang menanam sayur sawi sebanyak 100 orang. Pengambilan sampel menggunakan teknik simple random sampling.

Untuk mengetahui gambaran umum usahatani sawi di Kelurahan Bansone Kecamatan Kota Kefamenanu digunakan metode analisis deskriptif kualitatif. Selanjutnya dilakukan analisis cobb-douglas dengan menggunakan program SPSS version 16.0. Kemudian dilakukan uji koefisiaen determinan untuk mengetahui hubungan serta kekuatan variabel bebas (independentvariabel) menjelaskan variabel terikat (dependent variabel). Selanjutnya dilakukan uji " $F$ " untuk mengetahui secara nyata dan secara bersama-sama (simultan) pengaruh variabel bebas (X1-X7) terhadap variaber terikat (Y). Selanjutnya dilakukan uji "t" untuk mengetahui pengaruh parsial yaitu pengaruh dari $\mathrm{X}$ 1 terhadap $\mathrm{Y}, \mathrm{X} 2$ terhadap Y, X3 terhadap Y, X4 terhadap Y, X5 terhadap Y, X6 terhadap Y, dan X7 terhadap Y. Analisis dilakukan sesuai petunjuk Soekartawi (2003).

\section{Hasil dan Pembahasan}

\subsection{Deskripsi Usahatani Sayur Sawi}

Usahatani sayuran di lokasi penelitian memiliki luas lahan yang digunakan untuk bertanam sayur relatif luas yaitu sekitar 8 ha. Lahan di lokasi penelitian juga cukup staregis karena dekat dengan prasarana jalan sehingga memudahkan petani dalam pengangkutan hasil panen. dari pusat pasar Kabupaten sehingga memudahkan petani dalam memasarkan hasil usahataninya.

Berikut ini adalah tahap-tahap budidaya tanaman sawi antara lain persiapan dan pengolahan lahan, penyemaian, penanaman, perawatan dan pemeliharaan, panen dan pasca panen.

1. Persiapan dan Pengolahan lahan

Sayur sawi manis ditanam setiap bulan. Persiapan lahan dapat dimulai dengan membuat bedeng berukuran 2 atau 3 meter dan panjang bedeng dapat $d$ sesuaikan dengan ukuran lahan keseluruhan dan ketinggian bedengan 10 sampa $20 \mathrm{~cm}$. Setelah itu bedengan dibakar dengan menggunakan sabut kelapa dan cirit sapi dengan tujuan untuk menyuburkan tanah. 


\section{Penyemaian}

Tahap selanjutnya adalah penyemaian, benih di beli di toko pertanian, benih yang digunakan yaitu benih unggul untuk hasil panen yang maksimal. Setelah benih sawi manis di dapat, petani menyiapkan bedengan pembibitan dengan cara di canggul agar gembur. Setelah itu petani menaburkan benih pada permukaan tanah lalu menutup benih dengan tanah sekitar $2 \mathrm{~cm}$. kemudian petani melakukan perawatan dengan cara menyiram benih rutin tiap hari, setelah 3 atau 4 hari benih akan tumbuh. Tunggu benih sampai mempunyai 4 atau 5 helai daun, setelah itu benih sawi manis dipindahkan ke bedeng utama.

\section{Penanaman}

Penanaman dilakukan setelah bibit sawi manis mempunyai 4 sampai 5 helai daun. Sebelum penanaman bedengan disiram terlebih dahulu. Petani membuat lubang tanam pada bedengan dengan cara ditugal dengan jarak $20 \times 20 \mathrm{~cm}$. sebelum dicabut, semaian disiram terlebih dahulu agar akar tidak rusak. Bibi sawi manis ditanam 2 sampai 3 bibit satu lubang. Setelah itu siram dengan air secukupnya setelah selesai penanaman.

4. Perawatan dan Pemeliharaan

Perawatan dalam usahatani sawi adalah penyiraman secara teratur. Sebab tanaman sawi manis tergantung pada air, terutama saat musim kemarau. Langkah selanjutnya adalah penyiangan saat tanaman berumur 2 minggu, tujuan untuk membasmi gulma yang tumbuh disekitar bedengan, dan yang terakhir yaitu pemupukan yang mana pemupukan dilakukan sebelum penanaman dan pemupukan susulan setelah sawi manis berumur 2 minggu setelah tanam. Jenis pupuk yang dipakai petani adalah pupuk urea.

\section{Panen dan Pasca Panen}

Petani melakukan pemanenan setelah tanaman sayur sawi manis berumur 40 sampai 50 hari hari, panen sawi manis dapat dilakukan petani dengan mencabut tanaman. Petani melakukan pemanenan pada saat pagi hari dengan tujuan dijual kepada pedagang pegumpul atau bisa dijual sendiri. Sebelum dipasarkan sawi manis dicuci terlebih dahulu agar bersih dari tanah dan kotoran.

\subsection{Analisis Cobb-Douglas}

Analisis yang digunakan pada penelitian ini adalah analisis regresi berganda dalam bentuk logaritma dengan fungsi produksi Cobb-Douglas. Fungsi Cobb - Douglas digunakan untuk menguji pengaruh antara variabel independen terhadap variabel dependen (produksi sayur sawi). Dari angka korelasi pada tabel kemudian dilakukan model pendugaan dengan cara regresi yang hasilnya disajikan pada Tabel 1.

\section{Tabel 1 Analisis Varians}

\begin{tabular}{lccccc}
\hline \multirow{2}{*}{ Variabel } & \multicolumn{3}{c}{ Koefisien bel } & \multicolumn{2}{c}{ Koefisien baku } \\
\cline { 2 - 4 } & $\mathrm{B}$ & Std. Error & Beta & $\mathrm{T}$ & Sig. \\
\hline (Constant) & .666 & .927 & & .719 & .476 \\
Luas lahan (X1) & 1.120 & .274 & .628 & 4.090 & .000 \\
Bibit (X2) & .222 & .113 & .125 & 1.974 & .055 \\
Modal (X3) & .179 & .072 & .153 & 2.479 & .017 \\
Pupuk (X4 & .029 & .201 & .017 & .146 & .885 \\
Tenaga kerja (X5 & .214 & .077 & .089 & 2.785 & .008 \\
Pengalaman (X6) & .035 & .032 & .016 & 1.117 & .270 \\
Pendididkan (X7) & .013 & .039 & .005 & .321 & .750 \\
\hline Sumber: Data Primer Dion
\end{tabular}

Sumber: Data Primer Diolah, (2016)

Berdasarkan tabel diatas maka dapat diperoleh hasil dari fungsi cobb douglas sebagai berikut : $\mathrm{LnY}=\operatorname{Ln} 0.666+0.628 \operatorname{Ln} X_{1}+0.125 \operatorname{Ln} X_{2}-0.153$ $\operatorname{Ln} X_{3}+0.017 \operatorname{Ln} X_{4}+0.089 \operatorname{Ln} X_{5}+0.016 \operatorname{Ln} X_{6}+0.005 \operatorname{Ln} X_{7}$

\subsection{Analisis Uji Keragaman (Uji F)}

Uji F dilakukan untuk mengetahui apakah variabel-variabel (luas lahan, benih, tenaga kerja, pengalaman, pendidikan formal) secara bersama-sama mempengaruhi produksi usahatani sayur sawi dengan membandingkan rata-rata kuadrat regresi dengan rata-rata kuadarat residu dan hasilnya dapat dilihat dalam Tabel 2.

Tabel 2 Analisis $\mathrm{F}_{\text {hitung }}$

\begin{tabular}{llccccc}
\hline & Model & $\begin{array}{c}\text { Jumlah } \\
\text { Kuadrat }\end{array}$ & Df & $\begin{array}{c}\text { Jumlah } \\
\text { Rerata }\end{array}$ & Fhitung & Ftabel \\
\hline 1 & Regression & 26.476 & 7 & 3.782 & 712.476 & $2,32(5 \%)$ \\
& Residual & .223 & 42 & .006 & & \\
Total & 26.698 & 49 & & & \\
\hline
\end{tabular}

Sumber: Data Primer Diolah, (2016)

Berdasarkan analisis regresi Tabel 2. dapat dilihat bahwa nilai $F_{\text {hitung }}$ $(712.476)>$ dari nilai $\mathrm{F}_{\text {tabel }}(2,32)$. Dengan demikian, hipotesis alternatif $(\mathrm{Ha})$ yang menyatakan bahwa: ada pengaruh faktor luas lahan, faktor bibit, faktor modal, faktor pupuk, faktor tenaga kerja, factor pengalaman dan factor pendidikan terhadap hasil produktivitas sayur sawi, diterima. Dengan demikian dapat disimpulkan secara statistik dapat dibuktikan bahwa semua variabel independen luas lahan, bibit, modal, pupuk, tenaga keja, pengalaman, dan pendidikan secara bersama-sama (simultan) berpengaruh terhadap variabel hasil produktivitas sayur sawi.

\subsection{Analisis Koefisien Regresi (Uji t)}

Pengujian koefisien regresi parsial atau uji t digunakan untuk menguji apakah hipotesis yang diajukan dalam penelitian ini diterima atau ditolak dengan mengetahui apakah variabel independen secara individual mempengaruhi variabel dependen. Dengan melihat $t_{\text {hitung }}$ pada print out komputer dan nilai $t_{\text {tabel }}$ $(1,684(10 \%)$ pada tingkat kepercayaan 90 persen $(\alpha=10$ persen $)$,

1. Pengaruh Luas Lahan (X1) Terhadap Produktivitas sayur Sawi (Y)

Berdasarkan analisis data, diketahui $t_{\text {hitung }}$ luas lahan $(4.090)>t_{\text {tabel }}(1,684)$ dengan demikian Ho ditolak dan Ha diterima. Berdasarkan hasil uji statistik ini dapat disimpulkan, bahwa luas lahan secara parsial berpengaruh sangat nyata terhadap hasil produktivitas sayur sawi. Hal ini berarti makin besar luas lahan yang digarap untuk berusahatani sawi maka makin meningkatkan produksi sayur sawi. Nilai koefisien Regresi Luas Lahan (X1) sebesar 0.628 artinya setiap penambahan 1 (satu) persen luas lahan akan meningkatkan produksi sebesar 0.628 persen dengan asumsi variabel lain dianggap tetap.

2. Pengaruh benih $(\mathrm{X} 2)$ terhadap produktivitas sayur sawi $(\mathrm{Y})$

Berdasarkan analisis data, diketahui $\mathrm{t}_{\text {hitumg }}$ benih(1.974) $>\mathrm{t}_{\text {tabel }}(1.684)$ dengan demikian Ho ditolak dan Ha diterima. Berdasarkan hasil uji statistik ini dapat disimpulkan, bahwa benih secara parsial berpengaruh sangat nyata terhadap hasil produktivitas sayur sawi. artiya semakin besar jumlah benih yang digunakan maka akan menghasilkan produksi yang semakin tinggi. Hal ini juga disebakan karena petani ditempat penelitian selalu menggunakan benih yang unggul dan memiliki label. Nilai koefisien regresi benih (X2) sebesar 0.125 menunjukkan bahwa tiap penambahan 1 (satu) persen jumlah benih akan meningkatkan produksi sebesar 0.125 persen dengan asumsi variabel lain dianggap tetap.

3. Pengaruh modal (X3) terhadap produktivitas sayur sawi $(\mathrm{Y})$

Berdasarkan analisis data, diketahui $\mathrm{t}_{\text {hitung }}$ modal $(2.479)>\mathrm{t}_{\text {tabel }}(1.684)$ dengan demikian Ho ditolak dan Ha diterima. Berdasarkan hasil uji statistik ini dapat disimpulkan, bahwa modal secara parsial berpengaruh secara nyata terhadap hasil produktivitas sayur sawi. Artinya semakin banyak biaya yang digunakan untuk usahatani sayur sawi maka semakin meningkatkan produksi sayur sawi. Nilai koefisien Regresi modal (X3) sebesar 0.153 artinya setiap penambahan 1 (satu) persen modal akan meningkatkan produksi sebesar 0.153 persen dengan asumsi variabel lain dianggap tetap.

4. Pengaruh pupuk urea (X4) terhadap produktivitas sayur sawi (Y)

Berdasarkan analisis data, diketahui $t_{\text {hitung }}$ pupuk $(0.164)<t_{\text {tabel }}(1.684)$ dengan demikian Ho diterima dan Ha ditolak. Berdasarkan hasil uji statistik ini dapat disimpulkan, bahwa pupuk secara parsial tidak berpengaruh secara nyata terhadap hasil produktivitas sayur sawi. Variabel pupuk urea berpengaruh tidak signifikan diduga karena pemakaian pupuk urea masih kurang, karena tanaman yang kekurangan nitrogen tidak dapat tumbuh dengan optimal sehingga proses pertumbuhan akan terhambat dalam hal ini petani harus menggunakan pupuk yang banyak mengandung nitrogen mengingat sawi dipanen daunnya dan juga manfaat pupuk nitrogen bagi tumbuhan sangat besar yaitu unsure nitrogen sangat berperan penting terhadap pertumbuhan tanaman. Nilai koefisien regresi pupuk urea (X4) sebesar 0.017 yang berarti bahwa setiap penambahan 1 (satu) persen pupuk urea akan menambah produksi sebesar 0.017 persen dengan asumsi variabel lain dianggap tetap.

5. Pengaruh tenaga kerja (X5) terhadap produktivitas sayur sawi $(\mathrm{Y})$

Berdasarkan analisis data, diketahui $t_{\text {hitung }}$ tenaga kerja (2.785) $>t_{\text {tabel }}(1.684)$ dengan demikian Ho ditolak dan Ha diterima. Berdasarkan hasil uji statistik ini dapat disimpulkan, bahwa tenaga kerja secara parsial berpengaruh sangat nyata terhadap hasil produktivitas sayur sawi. Variabel tenaga kerja berpengaruh sangat nyata karena Jika dilihat dari rata-rata penggunaan tenaga kerja, hasil peningkatan produksi sangatlah baik. Hal ini di sebabkan karena tenaga kerja yang digunakan berkeja dengan baik sehingga dapat membantu dalam meningkatkan hasil produksi. Nilai Koefisien regresi sebesar 0.089 yang menunjukkan apabila jumlah tenaga kerja bertambah 1 HOK akan meningkatkan produksi sebesar 0.089 persen dengan asumsi variabel lain dianggap tetap.

6. Pengaruh pengalaman (X6) terhadap produktivitas sayur sawi (Y)

Berdasarkan analisis data, diketahui $\mathrm{t}_{\text {hitung }}$ pengalaman $(1.117)<\mathrm{t}_{\text {tabel }}(1.684)$ dengan demikian Ho diterima dan Ha ditolak. Berdasarkan hasil uji statistik ini dapat disimpulkan, bahwa pengalaman secara parsial tidak berpengaruh secara nyata terhadap hasil produktivitas sayur sawi. variabel pengalaman tidak berpengaruh nyata diduga karena petani di daerah penelitian tidak belajar dari pengalaman yang mereka miliki sebelumnya, artinya pada waktu tanam sebelumnya jika hasil produksinya meningkat maka hal ini harus dipertahankan pada masa tanam berikutnnya. Tetapi petani tidak mempertahankan hal tersebut sehingga hasil produksi sawi tidak meningkat. Nilai koefisien regresi benih (X2) sebesar 0. 016 menunjukkan bahwa tiap penambahan 1 (satu) persen jumlah pengalaman akan meningkatkan produksi sebesar 0.016 persen dengan asumsi variabel lain dianggap tetap.

7. Pengaruh pendidikan formal (X7) terhadap produktivitas sayur sawi $(\mathrm{Y})$

Berdasarkan analisis data, diketahui $\mathrm{t}_{\text {hitung }}$ pendidikan $(0.321)<\mathrm{t}_{\text {tabel }}(1.684)$ dengan demikian Ho diterima dan Ha ditolak. Berdasarkan hasil uji statistik ini dapat disimpulkan, bahwa pendidikan formal secara parsial tidak berpengaruh secara signifikan terhadap hasil produktivitas sayur sawi. Pendidikan formal tidak berpengaruh nyata terhadap produksi sawi karena tingkat pendidikan petani di daerah penelitian masih rendah. Hal ini diketahui dari presentase tingkat pendidikan responden terbanyak berada pada tingkat pendidikan sekolah dasar sehingga menyebabkan rendahnya produktifitas tenaga kerja dan manajemen di sector pertanian. Nilai koefisien regresi benih (X7) sebesar 0.005 menunjukkan 
bahwa tiap penambahan 1 (satu) persen tingkat pendidikan akan meningkatkan produksi sebesar 0.005 persen dengan asumsi variabel lain dianggap tetap.

\subsection{Analisis Uji Koefisien Determinasi (R2)}

Koefisien determinasi adalah besarnya keragaman variabel terikat $(\mathrm{Y})$ yang mampu dijelaskan oleh seluruh variabel bebas $\left(\mathrm{X}_{\mathrm{i}}\right)$ dalam model Nilai koefisien determinasi merupakan perbandingan antara jumlah kuadrat regresi dengan kuadrat total dapat dilihat pada Tabel 3.

Tabel 3. Analisis Koefisien Determinasi $\left(\mathrm{R}^{2}\right)$

\begin{tabular}{ccccc}
\hline Model & $\mathrm{R}$ & R Square & $\begin{array}{c}\text { Adjusted R } \\
\text { Square }\end{array}$ & $\begin{array}{c}\text { Std. Error of the } \\
\text { Estimate }\end{array}$ \\
\hline 1 & $.886^{\mathrm{a}}$ & 0.784 & 0.88 & 0.07286 \\
\hline
\end{tabular}

Sumber: Data Primer Diolah, (2016)

Dari Tabel 3. dapat dikatakan bahwa dalam model variabel independen(luas lahan, bibit, modal, pupuk, tenaga kerja, pengalaman, pendidikan)secara bersama-sama berpengaruh terhadap variabel dependen(produksi usahatani sayur sawi) sebesar 78,4\% sisanya yaitu sebesar $21.6 \%$ dipengaruihi oleh faktor lain yang tidak diuji dalam penelitian ini.

\section{Simpulan}

Usahatani sayur sawi diawali dengan (1) persiapan dan pengolahan lahan dengan cara dibakar kemudian diolah dan dibentuk bedengan dengan ukuran tertentu; (2) penyemaian. Taburkan benih pada permukaan tanah lalu tutup benih dengan tanah,lakukan perawatan dengan menyiram benih rutin setiap hari; (3) penanaman yang dilakukan dengan cara di tugal dengan jarak antara lubang $20 \mathrm{~cm}$ dan pada tiap lubang ditanami 2-3 bibit sayur sawi; (4) pemeliharaan dilakukan setelah tanaman berumur 2 minggu; (5) pemanenan sawi manis dapat dilakukan dengan mencabut tanaman beserta akarnya kemudian memotong akarnya. Secara bersama-sama (simultan) faktor luas lahan, benih, modal, pupuk, tenaga kerja, pengalaman dan pendidikan formal berpengaruh nyata pada produksi usahatani sayur sawi. sedangkan secara sendiri-sendiri (parsial) faktor luas lahan, benih, modal, tenaga kerja berpengaruh secara nyata terhadap produksi usahatani sayur sawi sedangkan faktor pupuk, pengalaman dan pendidikan formal tidak berpengaruh secara nyata terhadap produksi usahatani sayur sawi.

\section{Pustaka}

Badan Pusat Statistik Kabupaten TTU. 2014. TTU Dalam Angka 2014. Kefamenanu

Dinas Pertanian Kabupaten Timor Tengah Utara. 2014. Data Produksi Tanaman Holtikultur. Kefamenanu

Hapsari, B. 2002. Sayuran Genjah Bergelimang Rupiah. Trubus 33 (396): 30 31.

Haryanto, W., T. Suhartini dan E. Rahayu. 2006. Sawi dan Selada. Penebar Swadaya, Jakarta.

Lamusa, Arifuddin. 2005. Faktor-Faktor Yang Mempengaruhi Produksi Kangkung Air Di Desa Tulo Kecamatan Dolo Kabupaten Donggala Propinsi Sulawesi Tengah. Jurnal Agroland 12. Program Studi Agribisnis Fakultas Pertanian Universitas Tadulako.

Mufriantie, Fithri dan Feriady, Anton. 2014. Analisis Faktor Produksi dan Efisiensi Alokatif Usahatani Bayam (Amarathus Sp) Di Kota Bengkulu. Jurnal Agrisep Vol. 15 Program Studi Agribisnis, Fakultas Pertanian Universitas Muhammadiyah.Bengkulu.

Rahman, A., Hermaya, dan Lisa. 2008. Pertumbuhan dan Produksi Sawi Dengan Pemberian Bokashi, Jurnal Agrisisten 4(2): 75-80

Rukmana, 2002. Bertanam Petsai dan Sawi. Kanisius, Yogyakarta.

Soekartawi, 2003. Teori Ekonomi Produksi Dengan Pokok Bahasan Analisis Fungsi Cobb Douglas. PT. Raja grafindo persada, Jakarta 